\title{
Concept of time in language and text (contextual time markers)
}

\begin{abstract}
The aim of this paper is to study different time representations in language and text. Time is an abstract category firmly connected to human life, it can be considered to be the fourth dimension of reality, used to describe events in three-dimensional space. Time has been studied from different points of view and in different aspects. The perception of time can vary depending on the social and cultural environment. That is why it is so important to pay special attention to a variety of time representations when studying a foreign language. In this article I consider different time markers represented in language (English and Russian) and contextual time markers we can find in texts for reading comprehension activities at advanced levels when studying Russian as a foreign language. I compare language and contextual time markers using a cognitive approach to text units. As an example, I take time markers from the texts published in a popular Russian literary magazine Novy mir at the turn of the 21 century. Novy mir is a very famous in Russia for its liberal position and history within the dissident movement during Soviet epoch
\end{abstract}

Keywords: concept of time, time markers, text and discourse, cognitive linguistics

\section{Time in language}

Time has always been a subject of study in different fields including history, philosophy, religion or science. Thinkers have conceptualized and analysed time in different ways. Plato, Aristotle, Saint Augustine, Kant, Newton, Einstein, Spengler, Vernadsky, Bergson and other philosophers and scientists discussed the nature of time and its physical and psychological aspects. Time is one of the basic concepts related to our perception of reality. In this article, I discuss language as a means for structuring, representing, and 
conceptualizing time. It is important to understand that 'time' refers to different ideas. The perception of time can vary depending on cultural environment and the language spoken. To study the idea of time in language I compare English and Russian definitions of time. "Time is the indefinite continued progress of existence and events that occur in an apparently irreversible succession from the past, through the present, into the future". From this Wikipedia definition we can divide time into three: past, present and future. Webster dictionary gives us 14 meanings for time. The word time "can mean: duration, leisure, occasion, age, lifetime, season, tempo, rhythm and turn. It can be used as a noun, verb and adjective. Apart from these meanings there is a specific concept of tense in English - a grammatical category which is marked by verb inflection and expresses when an event or action happens in the flow of time. In Russian all meanings of the word time represented in the Great Explanatory Dictionary (Bolshoy Tolkovy slovar) are divided into four general definitions. Time is:

1. A philosophic category, for example: the infinity of space and time (бесконечность пространства и времени);

2. A period of time (connected to an activity), for example: spring time, free time (время весны, свободное время);

3. An epoch, a wider period (used both in singular and in plural), for example: wartime, at all times (военное время, на все времена);

4. A category of grammar (synonym of tense in this meaning), for example: determine the tense of the verb, form the past participle, literally: form the participle of past time (определить время глагола, образовать причастие прошедшего времени).

So, the concept of time represented in the language systems of English and Russian and described in dictionaries is quite similar but its representation is more detailed in English.

\section{Language time markers}

When I speak about language time markers I mean lexical time markers. Lexical time markers can be extracted them from the definition of the word time. For example, from the Russian definition I extracted the following synonyms: sequence, duration, change, segment, interval, leisure, period, era (последовательность, продолжительность, изменение, отрезок, интервал, досуг, период, эпоха); and the following time markers: initially, once, at the same time, soon constantly, at the beginning, timely, temporarily (первоначально, однажды, в то же время, скоро постоянно, в начале, своевременно, временно). Then I can mention morphological time markers: tense and aspect (Mithun, 2019). Tense and aspect are verbal categories, where the most common reference point is the moment of speech. Events can be divided into the past for situations before the time of speech, present for those overlapping with the moment of speech, and future for those subsequent to the moment of speech. In some works, studying time and language among linguistic means of time refer to: reduplication (for example, he ran and ran and ran to express the process is extended over time); intonation (for example, vowel lengthening to indicate a long time duration); and even body movement, like quick movements to show 
that something happens quickly (Allwood, 2003). Strictly speaking, linguistic time markers can be divided into lexical (nouns and adverbs of time), grammatical (verbs), phonetical (as intonation is a part of phonetics), syntactical (reduplication and other means of syntax) and extra-linguistic (body language). As can be seen from the above, only lexical and grammatical time markers are reflected in dictionaries and can be easily understood by students learning a foreign language (in the article we mean students learning Russian as a foreign language). Other time markers can be represented in context, otherwise understanding and interpretation can be blurred. To avoid these difficulties, I studied time markers in modern Russian literature and present the results below.

\section{Time in context}

In this section I compare linguistic versus contextual markers of time. In other words, I connect language as a structure and cognition. This approach is possible within cognitive linguistics. Being a part of the whole complex of cognitive sciences, cognitive linguistics studies processes and mechanisms of extraction, storage and transmission of knowledge through language. Cognitive linguistics tries to answer the question, how exactly does a person perceives reality, what are the objective and subjective factors are taking part in the formation of vision of the world by a particular ethnic group. Each text is read by a person with his/her own mentality, vision of reality and linguistic picture of the world. So, each text exists as a structure or a text itself and as a discourse, or a text with a several senses, meaning, associations, ideas, etc., connected to it in the process of (1) creating and (2) reading. Discourse analysis allows us to consider a text from the point of view of mental processes and in connection with extralinguistic factors. This approach makes it possible to identify new actual meanings, or meanings not recorded in dictionaries or grammar guides. Discourse knowledge varies in time and space: our understanding and interpretation of a text we read depends on our actual vision of life, social and cultural values of the society we belong and many other factors. It's important that both authors' and readers' cognitive fields should be the same or overlap to comprehend a text. If we speak about reading in a foreign language we need to be sure that both text (language as a structure) and discourse (language as a cognition) are comprehended. This can be a more complex task when reading an original text in a foreign language, because each word in text gets a new life; it creates a new aura or a new cognitive field where new connotations and, as a result, new meanings of words are attracted and start collaborating in a different manner. Of course, this is true for significant (for an author or a reader) concepts. Extensive text fragments and even whole areas of culture are concentrated around these key concepts, and concept of time is one of those. I studied the concept of time in modern Russian prose created in the end of $20^{\text {th }}$ - beginning of $21^{\text {st }}$ century and published in one of the most popular literary edition in Russia. Novy Mir is monthly literary magazine, famous for its dissident position, controversial articles, criticism of the government and a general liberal orientation. We can say that the discourse of Novy Mir is a reflection of the intellectual state of modern Russian society. I chose 'time' because this concept obtains 
a specific significance between two centuries and a new millennium, it was especially important for Russia in the period of falling of the Iron Curtain and perestroika. Those and other important changes were reflected in the texts published in Novy Mir.

\section{Contextual time markers}

The structure of a concept is similar to an associative field of a word, where relative words and expressions are involved. In literary texts this attraction is stronger and wider because of a context where a word starts "living a new life". A structure of a concept has a core part and periphery. In context, the word 'time', along with its lexical (vocabulary) meaning discussed above, obtains new connotations and additional meanings. It can be seen that apart from the linguistic meaning described above the word time acquires new meanings and connotations. Among them there are the following:

1. time as a picture (time is coloured with new colours / время расцвечено новыми красками)

2. time as a book / a text (historical text of time / исторический текст времени)

3. time as a space (time as a field / время как поле).

In the peripheral part of the concept of time there are the regular language time markers mentioned above. But the development of the discourse involves other parts of speech, semantic and syntactical constructions and an even bigger part of the text in time representation. We can see not only sequence of events but can construct historical time. In other words, we can understand a text not only as a structure but as a discourse. This is very important when one reads a text in a foreign language. Among the contextual time markers I found in the texts published in Novy Mir magazine at the turn of the century, the most frequent were the following (I give some examples from the magazine in Russian with our English translation): 1. Proper names: historical characters, politics, artists, actors, names of books, newspapers, magazines, films, etc.

Ведь в сапогах шел не любимый писатель Ольги Юрий Трифонов, которого она только что переплела, вырвав из "Нового мира" (Translation: After all, in his boots was not a favorite Olga's author Yuri Trifonov, which she had just kept, tearing of the "New World") (Novy Mir, 1998: 2, 17)

2. Toponims, geographical points

Ванда - спец по лекарствам, отправляет их в Союз, извиняюсь, в Россию, но не через Ольгу. (Translation: Wanda is a specialist in medicines, she sends them to the Union, sorry, to Russia, but not through Olga). (Novy Mir, 1998: 2, 6)

\section{Social status}

И пока он (Кулибин) подгонял слова к выходу, парторг сказал:

- Тебе, конечно, проще. У тебя жена бэзнэсмэн. - Он так именно сказал, припадая на неправильную гласную (Translation: And while he (Kulibin) urged the words in order to exit, the communist party functionary said:

- Of course, it's easier for you. You have a businessman wife. - He just said it like that, using the wrong word) (Novy Mir, 1998: 2, 47) 


\title{
4. Realia (objects and material from everyday life)
}

\begin{abstract}
Настраивал старенький приемник “Альпинист” на волну вещавшего до пяти утра рок-н-рольного радио, где музыка перемежалась веселым козлоглагольствованием каких-то случайных ведущих (Translation: I was tuning an old Alpinist radio receiver to a wave of rock and roll radio broadcasting until five in the morning, where the music was interspersed with the cheerful goat talk of some random hosts. (Novy Mir, 1999: 1, 23)
\end{abstract}

5. Precedent texts or phenomena (texts that are cognitively or emotionally significant, widely known by a linguacultural community; quotations or allusions to well-known texts):

\begin{abstract}
Замерев на пороге...своей квартиры, я думала, что в моей стране квартира и отдельный бачок будут посильнее “материализма и эмпириокритицизма", взятых вместе с автором (Translation: Standing on the threshold ... of my apartment, I thought that in my country an apartment and a separate water closet would be stronger than „materialism and empirio-criticism” taken together with the author) (Novy Mir, 1998: 2, 30)
\end{abstract}

Неверующий человек, Кулибин боялся умереть так, чтоб там ему было стыдно за бесцельно прожитые годы. Бодрая комсомольская цитата в его мозгу имела вот такой странноватый поворот. (Translation: A non-believer, Kulibin was afraid to die so that he would be ashamed of his aimless years there. The cheerful Komsomol quote had such a strange twist in his brain.) (Novy Mir, 1998: 2, 36)

\section{Temporal anchoring in language and context}

Temporal anchoring in language is connected to deixis (from lat. display, demonstration, or reference). Deixis is a sign, pointing to some aspect of its context of occurrence. In the case of the concept of time this sign is "now" of a speaker. All the language time markers I mentioned above are organised around the point of generating a text ("now" of a speaker). Even when one speaks of external ways of measuring time (referring to a clock or calendar) it is still connected to a speaker and his moment of speech. Each speaker divides the real time according his / her social and cultural traditions and preferences. For example, the sixth of January can be called the Christmas Eve in Russian orthodox church tradition, meanwhile in Catholicism or other Christian confessions this is not true. Speaking of language time markers it can be seen that all adverbs of time show a point before or after now. Verbal grammar is also organized around the "now" of a speaker, showing duration, beginning, continuation, punctuality or repeatability of a process or an action related to "now".

In case of contextual time anchoring there are several deictic points, because inside the text there are examples of (1) external time, (2) event time (chronology of events connected to the content of the text) and (3) narrator's time (perceptual, expressing the position of the speaker in relation to the events of the text). Time anchoring is not fixed by the moment of generating the text, it is mobile and can move according to the will of the narrator. Discourse time markers belonging to different timelines very often interact. Let us see some examples. 
Тогда недавно умер Шукшин, ....все интеллигентные люди как бы сплотились в горе. (Novy mir, 1998: 2, 23) (Translation: Then Shukshin died recently, ... all intelligent people rallied in grief)

In the above example we can find a proper name which can be both an external time reference (Russain writer Vasily Shukshin died in 1974) and a chronological point within the narration (тогда недавно literally can be translated from Russain as recently from that time).

Кулибин...имел довольно противную привычку укладывать...прядь волос поперек колена головы. А-ля Лукашенко, что из Белоруссии. (Novy mir, 1998: 2,35) (Translation: Kulibin ... had a rather nasty habit of styling ... a strand of his hair across the knee of his head. A la Lukashenko, who is from Belarus).

In the quote we can find a proper name functioning as a discourse time marker. It can refer both to the narrator's time and external time because Lukashenko became famous as president of the independent state of Belarus not earlier than 1994. Here we can see an interesting example when a narrator's deictic time point invades the event chronology, but does not coincide with it.

\section{Conclusions}

Time is an abstract category connected to human life. The perception of time can vary depending on the social or cultural environment. That is why it is so important to place different time markers in context. These "contextual" time markers can cause difficulties for students who study a foreign language. This article is directed at students who study Russian as a foreign language but the methods and results of the current research can be used more generally by those seeking to acquire a second language - in reading comprehension, translation and in the historical interpretation of a text.

\section{References}

Allwood J. (2003), Language and Time, [in:] Pajusalu R., Hennoste T. (eds.), Tähendusepüüdja. Catcher of the Meaning. Publications of the Dept of General Linguistics 3, University of Tartu, Finland, https://www.academia.edu/25321367/Language and Time [access: 15.07.2020].

Bolshoy Tolkovy Slovar [Great Explanatory Dictionary], Kuznecov S.A. (ed.), Norint, St Petersburg (1998), (Большой толковый словарь русского языка, Гл. ред. С. А. Кузнецов: СПб.: Норинт, 1998), http://gramota.ru/slovari/dic/?word=\%D0\%B2\%D1\%80\%D0\%B5\%D0\%BC\%D1\%8F\&all=x [access: 15.07.2020].

Mithun M. (2019), Tense and Aspect in Morphology, June 2019, online, DOI:10.1093/acrefore/9780199384655.013.548; https://oxfordre.com/linguistics/oso/viewentry/10.1093\$002facrefore $\$ 002 \mathrm{f} 9780199384655.001 .0001 \$ 002$ facrefore-9780199384655-e-548;jsessionid=9D42B 889941B543FFD672F82C017BD54 [access: 20.07.2020].

Novy mir, http://www.nm1925.ru/ [access: 20.07.2020]. 
Time, [in:] Webster's Dictionary, https://www.merriam-webster.com/dictionary/time? src=search-dict-box [access: 10.07.2020].

Time, [in:] Wikipedia, https://en.wikipedia.org/wiki/Time\#cite note-Poidevin-7= [access: 10.07.2020].

\section{Streszczenie \\ Koncept czasu w języku i w tekście (kontekstualne markery czasu)}

Celem niniejszego artykułu jest zbadanie rozmaitych prezentacji czasu w języku i w tekście. Czas - to abstrakcyjna kategoria, trwale związana z życiem człowieka, można go rozpatrywać jako czwarty wymiar realności, wykorzystywany do opisu wydarzeń w przestrzeni trójwymiarowej. Czas badano z różnych punktów widzenia i w różnych aspektach. Percepcja czasu może się modyfikować w zależności środowiska społecznego i kulturowego. Właśnie dlatego tak ważne jest zwrócenie uwagi na różnorodne przedstawianie czasu podczas nauki języka obcego. W artykule badamy rozmaite markery czasowe, przedstawione w języku (angielskim i rosyjskim) oraz kontekstualne markery czasowe, które możemy znaleźć w ćwiczeniach $\mathrm{z}$ rozumienia przeczytanego tekstu na poziomie zaawansowanym podczas nauki języka rosyjskiego jako obcego. Porównujemy językowe i kontekstualne markery czasowe, wykorzystując kognitywne podejście do jednostek tekstowych. Jako przykład wykorzystujemy czasowe markery z tekstów opublikowanych popularnym rosyjskim czasopiśmie literackim Novy mir na przełomie 21 wieku. Novy mir jest bardzo znany w Rosji ze swej niezmiennej liberalnej pozycji oraz historii ruchu dysydenckiego w czasach radzieckich.

Słowa kluczowe: koncept czasu, markery czasowe, tekst I dyskurs, językoznawstwo kognitywne 